\title{
Correction: Bone marrow plasma cells $20 \%$ or greater discriminate presentation, response, and survival in AL amyloidosis
}

Eli Muchtar 1 - Morie A. Gertz - Taxiarchis V. Kourelis - Surbhi Sidana 1 - Ronald S. Go • Martha Q. Lacy • Francis K. Buadi - David Dingli - Suzanne R. Hayman - Prashant Kapoor - Nelson Leung 1 - Amie Fonder • Miriam Hobbs - Yi Lisa Hwa • Wilson Gonsalves - Rahma Warsame - Stephen Russell • John A. Lust · Yi Lin • Steven Zeldenrust · S. Vincent Rajkumar · Robert A. Kyle · Shaji K. Kumar (D) Angela Dispenzieri

Published online: 29 July 2020

(c) The Author(s), under exclusive licence to Springer Nature Limited 2020

Correction to: Leukemia

https://doi.org/10.1038/s41375-019-0655-x.

Since publication of the original article, the authors noticed a small error in Table 3. The third BMPC category should have read " $\geq 20 \%$ " and not " $10-19 \%$ " as it was originally. This has been updated in both PDF and HTML versions of this paper. 